\title{
«Особый путь»: мифы, реальность, поиски выхода
}

\author{
Н.М. ПЛИСКЕВИЧ*
}

*Плискевич Наталья Михайловна - старший научный сотрудник, Институт экономики РАН. Адрес: 117218, Россия, Москва, Нахимовский проспект, д. 32. E-mail: ons@naukaran.com

Цитирование: Плискевич Н.М. (2019) «Особый путь»: мифы, реальность, поиски выхода // Мир России. Т. 28. № 2. С. 42-62. DOI: 10.17323/1811-038X-2019-28-2-42-62

Идеи об «особом пути» страны, как правило, выливаются в специфические теоретические построения там, где общество болезненно переживает сам факт своей отсталости или испытывает жестокое разочарование от опыта модернизации с использованием институтов, заимствованных у более успешных стран. При этом игнорируется, что эти институты были выработань в странах-донорах в ходе долгого эволюччионного развития по собственному «особому пути». Складывающаяся в результате ситуация требует анализа трех аспектов проблемы: 1) выделения идеологемы «особого пути» и ее роли в соичиально-экономических, политических и идеологических процессах в эксплуатирующей их стране; 2) определения своеобразия исторической, географической, культурной, сочиильно-экономической ситуации, которое лежит в основе особости развития данной страны; 3) поиска оригинальных шагов, позволяющих выйти из ситуации раth dependence и разработать программу преодоления преград, сдерживающих модернизационные устремления.

В настоящей статье все эти проблемы рассматриваются преимущественно на основе российской специффики. Показано, что сама идеологема «особого пути» нередко навязывается обществу государством и используется им в своих политических целях. В то же время подчеркивается определенная сложность выстраивания пути к подлинной модернизации, тем более в современном информационном мире, поскольку этот путь должен учитьвать и наличие «институциональньх рубчов», связанных с предшествующими неудачныли попьтками мобилизационных рывков. В этих условиях заметная роль отводится государству, от которого требуется гибкий подход к решению текущих проблем не через чрезмерное регулирование всех процессов, выливающееся в монополизм коллективизма «сверху», но благодаря поощрению инициатив самого общества, созданию им независимых организаций, которые для многих индивидов оказываются проявлениями коллективизма «снизу» или, другими словами, факторами формирования гражданского общества. Гармоническое соотнотение государства и гражданского общества лежит в основе благополучия современных развитых стран. 
Ключевые слова: «особый путь», модернизация, идеология, институциональные структуры, path dependence, институциональные рубцы, «индивидуализм - патернализм», коллективизм «сверху», коллективизм «снизу»

С конца 1990-х гг. в российском общественно-политическом дискурсе начала акцентироваться тема «особого пути» развития нашей страны, обострившаяся в 2000-х гг. Это неудивительно: к тому времени стало очевидным, что трансформация советской модели в новую - рыночную и демократическую - идет не так, как предполагалось на первых этапах этого процесса. Привнесенные из стран, добившихся наибольших успехов в создании постиндустриальной, информационной экономики, институты в отечественных условиях начали давать сбой, преобразуясь сообразно укоренившимся в стране политическим, социокультурным и прочим традициям. В итоге в, казалось бы, новую модернизированную форму было вмонтировано чуждое ей содержание. Все это провоцировало общее разочарование в реформах и нарастание популярности убеждения, что Россия - страна со своим уникальным путем развития, а значит, требуется не копировать образцы, доказавшие свою успешность в других странах, а опираться на собственные традиции, связанные прежде всего с ролью государства в социально-экономическом преобразовании страны.

Трудно отрицать, что такие настроения являются чем-то новым: как правило, они возникают в ситуациях, когда страна или болезненно переживает свою отсталость от соседей, или испытывает жестокое разочарование от очередной неудачной попытки совершить модернизационный рывок, но при этом используя привычные мобилизационные методы модернизации. Обычно подобные настроения выливаются в теоретические построения об уникальности собственного пути развития: так, еще в первой половине XIX в. в Германии появились идеи Sonderweg. Можно вспомнить и идеи русского социализма как своеобразный вариант «особого пути», идущий от А.И. Герцена к народникам и социалистам-революционерам и потерпевший поражение от более жесткого марксистско-ленинского варианта «особого пути», который реализовался в начале XX в., просуществовал более 70 лет, но в итоге закончился крахом.

В то же время сама идея «особого пути» в основе своей отражает банальный факт: любая страна неповторима по сути, обладает своими природными, географическими, историческими, культурными особенностями, которые сознательно или бессознательно фиксируются ее лидерами и воздействуют на ход исторического развития государства. Например, путь развития США уникален, начиная с колонизации североамериканского континента и войны за независимость от Англии и заканчивая условиями, в которых развивалась эта страна на протяжении всего XX в. Хотя о пути развития США как об «особом пути» и, соответственно, о выращенных на этом пути во многом специфических институтах, как правило, не говорят ни сами американцы, ни представители стран, пытающихся перенять их опыт, т.е. государства так называемого догоняющего развития. Тем не менее американская институциональная структура неразрывно связана со становлением и развитием именно этой страны, а значит, при имплантации каких-либо ее элементов (даже очень успешных) в другие условия вполне возможны и сбои, и искажения, которые реформаторы, вступившие на такой путь модернизации своих государств, должны предвидеть и находить свои решения при возникновении тех или иных трудностей. 
Более того, «особые пути» успеха разных стран западной цивилизации приводят к созданию в составляющих ее государствах институтов, существенно различающихся между собой. Так, видные специалисты по корпоративному управлению, сравнивающие его практики в ведущих странах Запада, отмечают, что «вполне обычная в Германии практика участия банков в формировании акционерного капитала считается в США нарушением закона; то, что японцы сочтут сотрудничеством, в Америке определяется как сговор; приемлемый для германских корпораций способ формирования совета директоров в США называют ошибочным, так как он чреват конфликтом интересов, и так далее, и тому подобное» [Мейер, Хессель, Лорш 1995, с. 60].

Однако сам факт оживления интереса к проблемам «особого пути» в современной России заставляет внимательно присмотреться к аргументам как сторонников, так и противников этой теории. Причем здесь представляется важным выделить «особый путь» как идеологему и «особый путь» как органично присущий каждой стране вариант развития. Не менее важен и вопрос о возможностях выхода из ситуации, получившей в литературе название «колея, обусловленная предшествующим развитием» (path dependence), предполагающий разработку программы преодоления преград, сдерживающих модернизационные устремления.

\section{«Особый путь» как идеологема}

Размышления об «особом пути» своей страны всегда порождены спецификой ее развития, попыткой объяснить, почему она отстает от своих соседей. В то же время помимо материального идеологема «особого пути», как правило, содержит и духовный компонент как элемент неповторимой ментальности народа, принимающей или отторгающей заимствования из практики более успешных государств. Важно, что эта идеологема отнюдь не ограничивается лишь пропагандистской составляющей, а отражает вполне серьезные попытки осмысления причин неудач, постигших ту или иную страну на пути модернизации. Причем идея «особого пути» в разных ситуациях и у разных народов наполнялась разнообразным идеологическим содержанием в зависимости от задачи, ставшей актуальной на том или ином этапе развития. Соответственно, и моральные оценки «особого пути» в рамках данной идеологии могут быть не похожи друг на друга.

Как правило, эти идеи оказываются востребованными в странах догоняющего развития, где отставание от более развитых соседей ощущается весьма болезненно. И хотя многое из идеологем XVIII и XIX вв. - предшественников сегодняшних рассуждений об «особом пути» - ушло в прошлое, сам факт их постоянного возрождения в новых исторических обстоятельствах в преображенных формах заставляет задуматься о причинах такого явления. Не случайно можно встретить работы, связывающие идеи современных сторонников идеи об «особом пути» России с немецкой концепцией Sonderweg, берущей начало прежде всего в знаменитой работе И. Гердера «Идеи к философии истории человечества». В такой интерпретации идея «особого пути» страны дает надежду на рывок в развитии, позволяющий с учетом как опыта передовых стран, так и собственных социокультурных резервов преодолеть свое отставание. Поэтому данная интер- 
претация окрашена оптимизмом, верой в еще не раскрытые резервы народа, которые позволят в короткие сроки не только догнать, но и опередить геополитических соперников.

В то же время концепция «особого пути» очень часто оказывается востребованной и в ситуации пессимистической, когда предпринятый страной модернизационный рывок, особенно основанный на мобилизационных методах, не дал тех результатов, на которые рассчитывали его инициаторы. В этих случаях энтузиазм (если он был) быстро затихает, а трудности реформирования, эффект от которого можно ожидать лишь в более-менее отдаленном будущем, вызывают большое недовольство населения. Как следствие, нарастают антиреформаторские настроения, которые в противоположность неоправданному оптимизму модернизаторов нередко обретают форму утверждений об «особом пути» своей страны, но уже с противоположным знаком. Акцент делается на бессмысленности выстраивания параллелей с более передовыми странами, и в этом случае идеологема «особого пути» обретает охранительный, консервативный характер, преувеличенная роль отводится заботе о традиционных ценностях. Однако, по сути, в этой форме она используется прежде всего как идеологическое обслуживание интересов тех промежуточных выгодоприобретателей от остановившихся на полдороге реформ, которые стремятся сохранить свои преимущества на максимально длительный срок (см., например, [Hellman 1998; Бусыгина, Филиппов 2012]).

Таким образом, в том или ином виде идеологема «особого пути» обычно присутствует в интеллектуальном пространстве стран догоняющего развития. В ней клубок факторов истории каждой страны облекается в те или иные идеологические мифы, и чей миф будет воспринят большинством, за тем окажется в данный конкретный момент и преимущество в «обработке мозгов».

Свои глубокие корни идеологемы «особого пути», бесспорно, есть и в российской истории, и во всем ее многовековом культурном развитии. Так, В.М. Живов, известный специалист по русской культуре и языку, отмечает, что российские идеи «особого пути» - «это не только манипуляция смыслами актуального политического дискурса, но и конструирования прошлого». Этот конструкт включает в себя и идеологические проблемы настоящего, и реальные элементы прошлого, в процессе конструирования переосмысленные и приспособленные к актуальной дискурсивной задаче, где «практическая деятельность теснится эстетикой этатистской утопии». «Особый путь, - констатирует ученый, - это дискурсивная манипуляция, призванная трансформировать отсталость из недостатка в достоинство» [Живов 2018, с. 56].

А.Л. Зорин, характеризуя построения современных поклонников идеи «особого пути» России как явно традиционалистские (хотя их предпочитают сегодня называть консерваторами), выделяет одну из их фундаментальных позиций - идею быстрого прорыва в будущее, который произойдет именно благодаря, а не вопреки современной российской отсталости и тяжелым проблемам. Стоит отметить, что в начале 1990-х гг. именно эта идея стала движителем предпринятого страной рывка в реформы, правда, довольно быстро сменившаяся разочарованием, как бывает с любой утопической иллюзией. В связи с этим А.Л. Зорин отмечает, что тогда Б.Н. Ельцин в качестве лидера страны, сумевшего одержать победы во многих политических битвах, «менее всего может быть заподозрен в наивности. Но невозможно подозревать его и в неискренности - просто 
слишком сильны были господствовавшие в культуре идеологемы, позволявшие надеяться шагнуть в будущее “одним рывком, одним махом, одним знаком”». Причем тогда «надежды президента разделяла значительная, если не подавляющая часть его соотечественников» [Зорин 2018, с. 50].

Это своеобразие отечественной ментальности было выделено в концепции А.С. Ахиезера, определявшего инверсионную логику как важнейшую черту русского культурного кода, как результат «стремления социального субъекта утвердить <.. > исторически сложившийся нравственный идеал, игнорируя существенное изменение социальных условий» [Ахиезер 1998, с. 194]. Еще в начале 1992 г., когда надеждами на быстрые реформы были заражены многие, он дописал заключительную часть своей работы «Россия: критика исторического общества», опубликованную лишь во втором издании в 1997 г. (первое издание вышло в начале 1991 г., до начала реформ). В ней он обосновывал идею о том, что происходящие в стране преобразования - отнюдь не путь к либеральным реформам, а типичная для нашей страны фаза развития, когда ослабление общегосударственного начала сопровождается ростом локализма - перехватом ресурсных потоков более низкими структурами власти (либо региональными, либо экономическими). Он утверждал, что эта фаза через некоторое время вновь начнет ослабляться, и все вновь вернется к концентрации ресурсов на государственном уровне [Ахиезер 1997]. Причем такое развитие для А.С. Ахиезера не означало, что страна вечно будет пребывать в этом порочном кругу, но выход из него он видел не в либерализационном рывке, а в медленном развитии на основе развитого утилитаризма, когда люди в своей повседневной деятельности сами начинают находить наиболее эффективные формы поведения. В его концепции развитой утилитаризм «с его ориентацией на прогресс производства требует развития личности, повышения ею ценности своего Я». Следовательно, утилитаризм «выступает как возрастающая в своей значимости пружина социальных изменений, сила, вынуждающая формировать новые средства», которая «подготавливает почву для либерализма с его растущей оценкой духовных ценностей» [Ахиезер 1998, с. 522].

Таким образом, крушение собственных иллюзий, опиравшихся на глубинные социокультурные основания, разочарование в реформах, оказавшихся на деле тяжелыми и совсем не кратковременными, спровоцировали появление уже ко второй половине 1990-х гг. потребности в возрождении идеологемы «особого пути». По сути, такому возрождению способствовало прежде всего то, что подавляющее большинство населения, воспитанное в советскую эпоху, не смогло стать самостоятельным субъектом начавшихся преобразований, которые предполагали создание новых институциональных структур, стимулирующих свободу выбора и ответственность за него.

Правда, нельзя не учитывать и того, что в новой ситуации все оказались отнюдь не в равных условиях. Государство (точнее - сложившиеся в новых условиях квазиэлиты, в значительной степени впитавшие в себя старую номенклатуру) вместо того, чтобы всемерно поддерживать развитие новых инициатив и охранять их акторов от разного рода преследований (со стороны и государственных, и криминальных структур), по большей части оказалось озабочено укреплением собственных позиций в новых условиях, переделом собственности и т.П. В целом же такая ситуация благоприятствовала востребованности патернализма и отрицанию потребности в свободе и ответственности за свои действия. 
На такие настроения хорошо ложится идеологема «особого пути», поскольку, как отмечает Б.В. Дубин, «проблематика выбора, то есть свободы и ответственности за свободу, в метафоре “особого пути" полностью отсутствует. И это не сбой или недочет - таково устройство и функциональное назначение анализируемой метафоры», которая характеризует мифологическое сознание и его последующие архаизирующие разновидности. При этом само утверждение этой метафоры, отвлекающей от реальности в сферу абстрактного будущего, содействует развитию общей несознательности, где «безответственности властей соответствует безответственность масс» [Дубин 2018, с. 253, 257]. Упрочение такой позиции стимулирует и современное телевидение (отнюдь не только и не столько в своей политической части, но прежде всего в развлекательной повестке). Однако такая манипуляция массовым сознанием несет в себе угрозу для поддерживающих ее властей, потому что в результате «толпы эмоционально взвинченных людей, слабо ориентирующихся в обстоятельствах», создают «общую эмоциональную атмосферу для непродуманных массовых разрушительных действий, направленных как против внешнего мира, так и против самих себя» [Ахиезер 2008, с. 329]. Такие люди, находясь во власти идеологической метафоры, предпочитают иллюзорные картины, позволяющие камуфлировать различие между абстрактными устремлениями и реальностью. При этом для масс представления об «особом пути» обычно обретают оптимистические, мессианские формы, связанные не с тем, чтобы показывать другим народам отрицательный пример, а, напротив, чтобы дать им направление к светлому будущему. Но и то и другое - иллюзия, а «философия особого пути живет лишь до тех пор, пока она востребована обществом» [Травин 2018, с. 76]. При этом ее эффективность, как правило, связана с ролью государства как проводника, призванного повести по нему «послушный народ», а история не раз демонстрировала, чем кончались такие «походы».

\section{«Особый путь» и специфика развития страны}

Однако для того чтобы идеологема «особого пути» не только появилась, но и овладела массовым сознанием, необходим целый ряд условий. Прежде всего к таковым можно отнести массовую неудовлетворенность уровнем жизни, а нередко и результатами предшествующей попытки модернизации, как правило, основанной на привнесении в отечественные условия прекрасно зарекомендовавших себя в более передовых странах институтов. История накопила немало примеров того, как подобные попытки модернизации оборачивались в новых условиях перерождением заимствованных институтов. В результате суть старых порядков оставалась нетронутой, а лишь слегка изменялась их форма, что ставило более сложный вопрос: почему страны, чьи элиты, казалось бы, искренне желали встать на путь модернизации (в отличие от множества государств, и рядовые граждане, и элиты которых вполне устраивают сложившиеся веками традиционные порядки), терпят поражение? Может быть, действительно, и в истории их развития, и в национальной культуре, и в естественных природных и географических условиях есть нечто столь незыблемое, что делает модернизационные усилия обреченными? 
Стоит также отметить, что в 1960-е гг. проблемы, связанные со срывом модернизационных устремлений вполне искренне настроенных на преобразования по западному образцу руководителей многих освободившихся от колониальной зависимости стран, стали предметом серьезных размышлений ученых. Еще в те времена Ш. Эйзенштадт отметил важные отличия в самой культуре бывших колониальных государств и динамичных, ориентированных на постиндустриальное развитие стран Запада [Eisenstadt 1973]. В таких государствах усиление «качественных характеристик современности» воспринимается населением как процесс разрушения и упадок своих традиций [Eisenstadt 1966]. В результате модернизационный порыв завершается «крахом относительно дифференцированной и осовремененной институциональной основы, заменой ее более примитивными институтами или вступлением страны в порочный круг провалов и срывов, зачастую влекущий за собой институциональную стагнацию и неустойчивость, а также системную угрозу способности вбирать в себя новые веяния» [Эйзенштадm 2010, с. 46]. С. Хантингтон также отмечал, что в таких случаях на место институциональной рационализации нередко приходят распад административных структур, унаследованных от эпохи колониализма, ослабление или даже разложение тех политических организаций, которые сформировались в период борьбы с ним [Хантингтон 2004].

При анализе проблем соответствия институциональных структур и укоренившихся в обществе традиций, препятствующих адекватному восприятию передовых общественных форм, которые способствуют быстрому прогрессу, исследователи чаще всего приходят к двум противоположным выводам: оптимисты признают, что в самом укладе жизни народа заложено отторжение чуждых институциональных инноваций, но такое положение не фатально, пессимисты, напротив, придерживаются мнения, что такие особенности культуры непреодолимы и фактор отставания неизбежен.

Первые, по сути, видят причины неудач предшествующей попытки модернизации (или выхода из колеи предшествующего развития (path dependence)) в неверно выбранном политическом курсе, в защите интересов тех, кто воспользовался результатами первого этапа реформ в ущерб остальному населению. Именно во имя охранения установившегося порядка (по сути - промежуточного в общем процессе модернизации государства как основного проводника такой политики) и используется идея «особого пути». Однако эта идея обычно нацелена не на поиски оригинальных способов преодоления возникших трудностей, не на поиск того самого «особого пути», подходящего именно для специфических условий своей страны, а на консервацию архаики, ложно понимаемой стабильности, которая на деле лишь камуфлирует накапливающиеся противоречия и проблемы.

В то же время оптимистам присуще убеждение, что «на сегодняшний день научных оснований для каких-либо выводов о том, является российская социетальная культура фактором тормозящим, ускоряющим или никак не влияющим на процессы модернизации, просто нет». Сторонники «особого пути» в политическом плане, по их мнению, являются консерваторами, но надежды на прогрессивные сдвиги в обществе всегда связываются с инициативой малых групп - агентов изменений. К таковым В.Л. Тамбовцев относит и чиновников высоких рангов, и владельцев/менеджеров крупных фирм, и предпринимателей. Все они имеют ресурсы, необходимые для осуществления масштабных социально-экономиче- 
ских преобразований. При этом немаловажны и «черты личностей потенциальных агентов модернизации - открытость новшествам, коммуникативные способности и т.п.» [Тамбовцев 2017, с. 128, 127], то есть в данном случае акцент переносится на личностный уровень.

К пессимистическим трактовкам «особого пути» можно отнести достаточно разнородную группу теорий, среди которых выделяется матричное направление. Его сторонники доказывают, что России присуща институциональная матрица, качественно отличная от матричной структуры стран Запада. Среди таковых у нас наиболее известны концепции рыночной и раздаточной экономики О.Э. Бессоновой и Х-Y матриц С.Г. Кирдиной [Бессонова 2015; Бессонова 2018; Кирдина 2014], можно также вспомнить о государственно-центричной матрице [Ворожейкина 2001].

В то же время относительно недавно появилась еще одна матричная концепция. Ее автор - шведский ученый С. Хедлунд, выпустивший в 2011 г. книгу «Невидимые руки, опыт России и общественная наука. Способы объяснения системного провала». В ней он предложил рассматривать историю развития России сквозь призму матрицы Московии. Эту матрицу он характеризует как «модель, идеальную для мобилизации ресурсов с целью защиты от врагов», которая «сделала существование врага необходимым условием для поддержания практики постоянной мобилизации ресурсов» [Хедлунд 2015, с. 187]. Соответственно выстраивались формальные и неформальные институты, и «трудно вообразить систему, которая эффективнее душила бы частное предпринимательство и инновации снизу» [Хедлунд 2015, с. 186]. Основная сложность, заключает ученый, состоит в том, что такая система «оказалась совершенно не восприимчива к попыткам - даже самым настойчивым - что-то в ней изменить» [Хедлунд 2015, с. 23]. Она складывалась веками, и в свое время позволяла успешно решать стоящие перед страной проблемы, но за те предыдущие успехи была заплачена дорогая цена, которую в настоящее время приходится платить отторжением модернизации. И «несмотря на поразительную внешнюю модернизацию России, которая произошла за последнее столетие, неформальные нормы, которые когда-то возникли для поддержки самодержавия, условных прав собственности и извлечения ресурсов в целях обороны, остались устойчивыми. Московитское наследие остается определяющей чертой институционального развития - и у Кремля, похоже, встречает мало возражений» [Hedlund 2017, p. 27]. Классификацию российского развития именно как особой матрицы, по мнению С. Хедлунда, делает возможной вся его историческая динамика, где «периоды авторитарного экономического роста и расширения военного присутствия завершаются трудными временами, которые, в свою очередь, приводят к авторитарному восстановлению прежнего порядка», иными словами, демонстрируется фундаментальная «преемственность институтов, которая сохраняется даже перед лицом радикальных переворотов» [Хедлунд 2015, с. 187, 188]1.

Отдельное направление классификации путей развития России представляет концепция, согласно которой корни российской специфики следует искать в том, что в стране так и не были разделены отношения власти и собственности. Права собственности веками оставались и во многом остаются до сих пор весьма зыбкими, владение теми или иными активами оказывается производным от отношений их владельца с власть предержащими. Сложилась специфическая конструкция -

Тему матрицы Московии продолжил А.П. Заостровцев [Заостровцев 2017]. 
«власть-собственность» ${ }^{2}$. Этой позиции придерживаются многие исследователи, начиная с востоковеда Л.С. Васильева [Васильев 1994], предложившего сам термин, заканчивая многими современными историками (например, Ю.С. Пивоваровым, называющим данный конструкт «властесобственность» [Пивоваров 2014]), и экономистами (Р.М. Нуреевым, Ю.В. Латовым, А.Б. Руновым [Латов, Нуреев 2017; Нуреев, Рунов 2002]).

Следует отметить, что авторы данной концепции характеризуют развитие российской цивилизации как единство прерывистости и непрерывности развития, подчеркивая, что в советский период страна совершила модернизационный рывок, превратилась в индустриальное и урбанизированное государство, опираясь именно на жесткую связку власти и собственности. Сам факт такого преобразования, с одной стороны, свидетельствует о наличии у системы «власти-собственности» резервов общественно-экономического развития прежде всего за счет использования мобилизационных возможностей, заложенных в данной системе. Кроме того, признание такого варианта развития подтверждает нелинейность социально-экономического развития в целом и возможность разных путей модернизации экономики. Но, с другой стороны, сторонники данной концепции указывают и на ограниченность такого рода развития, связанного с разрывом технологической модернизации и урбанистического устройства жизни и не соответствующего им социокультурного компонента общественного прогресса. В частности, Р.М. Нуреев и Ю.В. Латов пишут о таком состоянии современного российского общества как об особой российской цивилизации, представляющей собой своего рода двойную периферию - периферию «одновременно стран западного пути развития, основанного на частной собственности, и стран восточного пути развития, основанного на власти-собственности» ${ }^{3}$. Но в целом они констатируют, что в настоящее время «несомненным фактом является то, что разорвать зависимость собственности от власти - т.е. ликвидировать институт власти-собственности - до сих пор не удалось» [Латов, Нуреев 2017 , c. 28-29, 42], и государство по сравнению с обществом по-прежнему остается сильнее.

\section{Как выйти из порочного круга предшествующего развития}

В отличие от авторов, для которых идеологема «особого пути» представляется оправданием консервации существующего состояния (как минимум сохранения status quo, а как максимум обоснование закономерности попятного движения страны, демонтажа тех преобразований, которые способны в дальнейшем вывести

2 С критикой данной концепции относительно недавно выступил А.И. Колганов, противопоставляя ее как некий конструкт, заполнивший «определенный теоретический вакуум, когда оказалось, что догматическое прочтение работ классиков марксизма, созданных в середине XIX в., не может удовлетворить потребности в теоретическом объяснении проблем социально-экономического устройства древневосточных обществ» [Колганов 2017, с. 93]. Очевидно, что сторонники данной концепции учитывают замечания К. Маркса об азиатском способе производства, но главное в современной популярности концепции «власти-собственности» заключается в ее попытке объяснить проблемы современного развития многих стран. И для А.И. Колганова как последовательного марксиста оказываются теоретически и методологически неприемлемыми общие версии анализа обществ и реального социализма, и неудач постсоциалистической трансформации с позиций концепции «власти-собственности».

3 Напомню, что А.С. Ахиезер писал о российской цивилизации как об особой, промежуточной, в которой слой просвещенного общества тяготеет к либеральным ценностям, а основная масса населения - к традиционалистским. 
ее на путь, соответствующий требованиям новой, информационной, экономики), многие исследователи признают как данность специфические характеристики развития страны, а потому отторгают стандартные рецепты ее модернизации и ищут свои оригинальные методы. Это относится, по сути, к большинству известных вариантов объяснения особости российского развития - от матричного до «властесобственнического» или обращающихся исключительно к социокультурным факторам. Такое стремление в современных условиях вполне естественно, поскольку на наших глазах произошло не только послевоенное возрождение (и перерождение) Германии и Японии, которые, прежде всего в японском варианте, можно было бы объяснить внешним вмешательством победителей, особенно США. Конец XX в. был также ознаменован становлением «молодых южноазиатских тигров», вышедших из числа отсталых стран в группу современных передовых, в числе которых Китай и Индия.

Поэтому даже сторонники теорий разных матриц России и Запада пытаются смягчать их, вводя в анализ элементы, открывающие в перспективе возможности модернизации нашей страны, и обусловливая закономерность их появления как усложнением внутренних условий системы, так и внешними воздействиями окружающего и все более глобализирующегося мира. Но при этом авторы разных теоретических конструкций по-разному видят пределы эволюции исходной матрицы. Так, в последних версиях концепции С.Г. Кирдиной признается возможность комплементарности X-Y матриц, чего не было в ее более ранних работах (и, по сути, за что сегодня ее критикует О.Э. Бессонова). Ныне для С.Г. Кирдиной критерий успешности институциональных заимствований - «такое встраивание альтернативных форм в хозяйственную, политическую и идеологическую среды, которое не нарушает доминирование присущей государству институциональной матрицы» [Кирдина 2014, с. 260, 261]. То есть, по сути, тезис о незыблемости исходной матрицы остается, а само требование, чтобы встроенные альтернативные формы не нарушали институциональных основ, логически свидетельствует о необходимости подстраивания этих форм под основные, что на практике в итоге означает их деформирование и даже перерождение ${ }^{4}$.

О.Э. Бессонова трактует институциональную эволюцию как рыночных, так и раздаточных отношений как их конвергенцию, что, по ее мнению, эквивалентно переходу к порядкам открытого доступа, о которых писали Д. Норт и его коллеги. Этот процесс она видит как «новую эпоху в развитии человечества - эпоху интеграции на базе разнообразных сочетаний рыночных и раздаточных форм, способных создать условия для одновременной реализации принципов свободы и справедливости»

\footnotetext{
4 Такое представление основано на самой концепции Х-Ү-матриц как функционально различных институциональных систем, причем существующих параллельно с глубокой древности. Для обоснования этой позиции в Древнем мире в противовес Древнему Египту как построенному на принципах X-матрицы предлагается и параллельное развитие по принципу Ү-матрицы, которое обнаруживается в Месопотамии [Кирдина 2014, с. 89-96]. Думаю, знаток истории Древнего Востока, многие годы изучавший ее культуру и особенности функционирования разных его сообществ, Л.С. Васильев был бы весьма удивлен такой трактовке истории Древнего Междуречья. Причем мы не получаем ответа о том, как и почему исчезло столь прогрессивное образование. Сам Л.С. Васильев, характеризуя древние общества как общества с господством системы «власти-собственности», отмечал лишь зачатки в античном мире институтов, на основе которых позднее стали вырабатываться институты западноевропейской цивилизации. Не находя убедительных причин таких изменений в античном мире, он ограничился констатацией того, что там произошла некая мутация системы «власти-собственности», но именно она впоследствии дала впечатляющие плоды [Васильев 1994].
} 
[Бессонова 2015, с. 88]. Таким образом, данная концепция оставляет возможности для эволюции институциональных форм, включая наиболее существенные.

Более пессимистичен С. Хедлунд, хотя он и признает, что бывают «неординарные ситуации очень значительных изменений, происходящих сразу по многим направлениям в условиях полной неопределенности и существенного расхождения с преобладающими нормами, убеждениями и ожиданиями». Но в целом ученый все же склоняется к тому, что в подобных ситуациях «общественная наука сталкивается со сложностями, перед которыми на сегодняшний день она бессильна» [Хедлунд 2015, с. 381]. А вытекающие из этого «провалы системного подхода» безрадостны «прежде всего для беднейших стран мира, $<\ldots$.. > для всех тех, на кого влияют финансовые кризисы, провальные “перестройки", а также халтурные попытки внедрения демократии путем внешнего вмешательства» [Хедлунд 2015, с. 395-396].

Для Р.М. Нуреева ${ }^{5}$ и Ю.В. Латова представление о цели развития России как о превращении ее в часть западноевропейской цивилизации мало реально. С их точки зрения, наиболее плодотворна идея самоидентификации России как самостоятельной цивилизации. Авторы полагают, что, будучи пограничной между Западом и Востоком, Россия «может играть большую роль в канализации “конфликта цивилизаций” в русло взаимовыгодной институциональной конкуренции» [Латов, $H y$ реев 2017, с. 44]. Однако непонятно, каким образом, находясь в институциональных рамках системы «власти-собственности», она сможет выполнить эту задачу. Тем более что сегодня мы наблюдаем, как ряд стран Востока, оставаясь верными своим культурным традициям, все же отыскивают способы переплетения их с институтами передовых стран Запада, открывающих простор для постепенного преображения основы той системы, которую можно характеризовать как «власть-собственность».

Если же попытаться выявить общее, что присутствует и в разнообразных матричных концепциях, и в концепции «власти-собственности», в наибольшей степени характеризующих специфику институционального устройства России и других стран с подобной институциональной структурой, то можно обнаружить, что общее - это чрезмерная роль государства во всех социально-экономических, политических, идеологических и даже культурных отношениях. Именно поэтому анализирующий данную систему О.И. Шкаратан назвал ее этакратизмом, а тот вариант, который выкристаллизовался в России после падения коммунистического строя в 1991 г., - неоэтакратизмом. В частности, в последней на настоящий момент коллективной монографии под редакцией О.И. Шкаратана и Г.А. Ястребова дается четкое определение: «Природа сложившейся в постсоветской России социально-экономической системы - этакратизм в новой фазе его развития, т.е., другими словами, неоэтакратизм». И далее, развивая это понятие, О.И. Шкаратан подчеркивает, что неоэтакратизм образует «основу социально-экономического порядка всех стран, принадлежащих к евразийской цивилизации, причем стран с весьма несхожим уровнем развития, механизмом хозяйствования, специфической социально-политической системой». Эти общества различаются «степенью огосударствления собственности и уровнем концентрации хозяйственной власти, мерой открытости по отношению к внешнему миру, и ролью правящей элиты, и степенью авторитаризма, и масштабами влияния репрессивных органов. Но во

\footnotetext{
Р.М. Нуреев и А.Б. Рунов еще в начале 2000-х гг. описали процесс постсоциалистической переинституционализации системы «власти-собственности» [Нуреев, Рунов 2002]).
} 
всех этих обществах мы наблюдаем чрезмерную власть государственного аппарата управления. Речь при этом идет о бюрократии особого типа, сосредоточившей в своих руках как политическую, так и экономическую власть» [Шкаратан, Ястребов 2016, с. 96-97]. К сказанному, возможно, важно было бы добавить замечание Р.М. Нуреева и Ю.В. Латова, что государство «претендует на роль главного (или даже единственного) руководителя институто-строительством в постсоветской России, оставаясь главным участником воспроизводства институтов власти-собственности» [Латов, Нуреев 2017, с. 43]. А такое институтообразование, как отмечал еще в середине 2000-х гг. А.А. Яковлев, в итоге «означает, что угроза нарушения прав собственности в России сегодня исходит не от инсайдеров, а от госаппарата, преследующего свои бюрократические и политические цели» [Яковлев 2006, с. 132].

Но если в описываемых процессах столь велика роль госаппарата, т.е. формирующих его чиновников со своими принципами, включая и корпоративную мораль, то в анализе данных процессов нужно учитывать и этическую составляющую. Например, А.В. Оболонский проанализировал путь деградации отечественной бюрократии с нравственных позиций. Именно дефекты бюрократической морали, по его мнению, стали главной причиной общего кризиса доверия в стране - важнейшего тормоза не только модернизационного, но и любого развития экономического потенциала, который, в свою очередь, представляет собой проявление общего кризиса этических норм в обществе вообще и во властных элитах в частности [Оболонский 2016].

Современное состояние российского государства вообще и существенной части обладающего властью чиновничества вызывает чувство отторжения от него, естественное желание сокращения его функций. Между тем, как неоднократно отмечал В.М. Полтерович, успешности реформ благоприятствует как раз наличие сильного государства как силы, способной их реализовать [Полтерович 2007]. Правда, в этой ситуации вновь встает тот же этический вопрос, о котором шла речь выше, поскольку при создании модернизированных институтов «критически важно, в чьи руки эти институты и конструкты попадут» [Оболонский 2018, с. 47].

То есть признание государства как важнейшего актора модернизационных изменений - широко признанный факт. Разумеется, между государственниками и либералами (особенно - либертарианцами) идет постоянная дискуссия об объемах этого вмешательства. При этом государственники обычно подкрепляют свои построения данными социологических опросов, которые показывают, что при всем критическом отношении к существующим государственным институтам население в большинстве своем их одобряет. Более того, интересен тот факт, что население в своем отношении к таким базовым принципам общества открытого доступа, как уважение к закону, демократия и т.п., на словах по большей части их поддерживает. Но при ответах на наводящие вопросы выясняется, что, если представится случай, оно в массе своей готово и обойти закон, и прибегнуть к антидемократическим методам. Такой подход подкрепляет общую приемлемость для населения сложившихся принципов управления, нередко граничащих с произволом. Причем многие на индивидуальном уровне признают, что если бы для них представилась возможность вписаться в выстроенную государством систему и безнаказанно обходить закон, они готовы этим воспользоваться.

Такие настроения, казалось бы, подкрепляют как матричные, так и «властесобственнические» конструкции, опирающиеся на противопоставление индиви- 
дуализма и коллективизма, который трактуется исключительно как организуемый в государственных формах. Однако само противопоставление понятий «индивидуализм» и «коллективизм» при всей его привычности вряд ли можно признать убедительным: его истоки следует искать в тех временах зарождения экономической науки, когда популярными абстракциями были так называемые робинзонады, т.е. помещение индивида в искусственно сконструированную мысленную среду, где он может рассчитывать исключительно на свои средства, способности и т.п. Но в реальности любой индивид, даже придерживающийся либертарианских взглядов, не может не входить в тот или иной контакт с окружающими, создавать разного рода содружества для решения тех или иных задач. Это могут быть и фирмы, и крупные компании, и разнообразные сетевые сообщества, и некоммерческие организации, и волонтерские объединения, и многое другое. То есть само противопоставление индивидуализма и коллективизма в ситуации объединения людей в некое сообщество ошибочно (а человек, как известно, существо общественное). Да и роль государства как института, призванного не только поддерживать соблюдение законности и порядка, но и оказывать помощь слабым, не отрицается сторонниками либерализма (см., например, [Фридман 2006, с. 60]).

При соприкосновении индивида с обществом, неизбежно связанным с вступлением в некие коллективистские отношения, принципиально важно, как они строятся. Именно это «как» и лежит в основе тех разграничений, которые составляют базу матричных конструкций и противопоставления частнособственническо-рыночной системы системе «власти-собственности». Нельзя не признать, что в течение многих веков, когда основной опасностью для индивида были внешняя агрессия либо междоусобные столкновения различных мелких властителей, большинство стремилось к усилению государства (либо более сильного из местных властителей, который в итоге и становился главой государства), в результате чего государственнические отношения укреплялись долгие годы.

Однако сами коллективистские отношения, как показывает история многих стран, могут строиться как «снизу», исходя из конкретных потребностей людей, их создающих, так и «сверху», когда институты, скрепляющие сообщество, создаются и контролируются или местным властителем, или государством. Специфика исторического развития европейских стран заключается в том, что там, помимо консолидирующей общество государственной власти, очень рано начали развиваться и укрепляться формы коллективной организации «снизу», прежде всего в городах. И обе эти формы нашли способы и средства длительного сосуществования друг с другом, что и породило впоследствии ту специфику западноевропейской цивилизации, которая привела ее к успеху. Вспомним замечание А. Грейфа: «Поскольку институты отражают действия людей, мы должны в конечном случае изучать их как частный порядок, даже когда существуют государства. Рассматривая институты как правила, иногда в целях анализа полезно допустить, что государство обладает монополией на насилие и принуждение и может обеспечить выполнение правил. Но политический порядок и эффективное государство сами являются результатами. $<\ldots$..> Для понимания влияния государства нужно изучать мотивацию задействованных агентов» [Грейф 2015, с. 34].

В России формы самоорганизации «снизу» также существовали (например, порядки Пскова и Новгорода), но были задавлены государственническими структурами, выстраиваемыми «сверху». Правда, в условиях смуты или крайней опас- 
ности низовые формы самоорганизации нередко спасали страну, либо государство вспоминало о них, чтобы активизировать низовую активность (например, выход страны из смуты начала XVII в.), однако после того как опасность была ликвидирована, нужда в таких самоорганизованных образованиях пропадала. Другие же формы низовой самоорганизации (типа общин или купеческих гильдий) были встроены в общую государственную систему, контролируемую «сверху», и выполняли те или иные функции по ее обслуживанию.

Это присущее отечественной традиции преувеличенное по сравнению с другими странами значение государства как генератора общественных связей (по определению - вертикальных), которое в советский период стало просто всеобъемлющим, бесспорно, наложило свой отпечаток на все отечественные институциональные конструкции. В 2000-е гг., время возрождения системы «власти-собственности», государство стало энергично возвращать позиции, сданные в 1990-е гг., - сводить к минимуму возможности налаживания и развития неконтролируемых связей «снизу» и насаждать привычные по советским временам вертикальные связи «сверху».

Такая политика приветствовалась большинством населения по психологическим причинам: государство, принимая на себя все больше обязательств, теоретически должно было вместе с тем принимать на себя ответственность за решение связанных с ними жизненных проблем населения, всего того, что оно обещало контролировать. По сути, во все большем объеме ответственность за решение этих проблем индивид перекладывал на государство, поскольку возможность снять ее с себя всегда комфортна, даже в условиях высокоразвитого общества. Но такая политика вместе с тем ярко выявила, что, с одной стороны, в противопоставлении европейского и российского вариантов развития точнее было бы рассматривать не антитезу «индивидуализм - коллективизм», а «индивидуализм - патернализм». Государство, сосредоточивая на себе и те связи, которые вполне могли бы быть организованы людьми «снизу», тем самым освобождало их от ответственности за результаты этих заблокированных связей. И чем шире оно распространяло свои инструменты регулирования, тем больше вторгалось в организацию повседневной жизни людей. Еще одним побочным результатом такой ситуации оказалась атомизация общества: государство, стремящееся монополизировать институциональное строительство в рамках кажущейся ему оптимальной концепции, противодействовало процессам низовой самоорганизации социума.

Однако, с другой стороны, представляется, что именно это стремление взять все под контроль может служить толчком к эволюции системы «власти-собственности» (или матриц разного типа). Предлагаемые обществу «сверху» социальные обязательства нередко оказываются невыполнимыми ввиду дефицита ресурсов, что подрывает основы патернализма, на котором во многом держится вся система. Разумеется, патерналистские настроения очень развиты в нашем обществе, тем более что патернализм, как уже было сказано, - состояние весьма комфортное для обывателя, и он вполне готов воспользоваться этим «даром» ${ }^{6}$. Но государство (прежде

\footnotetext{
6 Правда, там, где существуют развитые институты, дающие свободный доступ к проявлению личной инициативы как импульсу развития, патернализм не выходит за пределы определенных рамок. Пример - недавний референдум в Швейцарии, где большинство отвергло идею о выдаче каждому гражданину без каких-либо условий ежемесячной суммы, достаточной пусть и для скромной, но вполне достойной жизни, поскольку граждане посчитали это опасным для развития страны.
} 
всего с неустойчивой экономикой) отнюдь не всегда и не для всех готово выполнять свои обязательства (подробнее см. [Плискевич 2018]). И патерналистские настроения хотя и продолжают господствовать в российских массах как некий идеал, в реальности уже практически размыты. Свидетельством тому могут служить ответы на два вопроса в мониторинговых опросах Левада-Центра. На протяжении 2000-х гг. положительные ответы на вопросы, касающиеся социальной защиты населения и обязанности государства обеспечивать всем гражданам «нормальный уровень благосостояния», составили 50-60\%. К ним можно прибавить и $25 \%$ респондентов, которые считали, что государство обязано помогать всем попавшим в «трудное положение». Число выступающих за помощь государства людям, которые не в состоянии позаботиться о себе сами, колебалось от 17 до $25 \%$. Тех же, кто считал, что люди сами должны заботиться о себе, насчитывалось лишь 2-4\%. Однако в те же годы 74-79\% населения считали, что в трудной ситуации можно рассчитывать исключительно на собственные силы, хотя 17-25\% рассчитывали все же на поддержку со стороны общества и государства [Общественное мнение-2016 2017 , с. 22]. Вполне возможно, что респонденты, отвечая на вопросы, идеализировали представления, прокламируемые, но фактически далеко не всегда исполняемые в советское время, при одновременном осознании неутешительной объективной реальности наших дней. Государство, поддерживая указанные идеальные представления в целях обеспечения стабильности, стремится взять под контроль максимум сфер жизни и общества в целом и индивидуумов в частности, но оно не способно обеспечить нормальное функционирование всего взятого под контроль, а значит, ставится вопрос о его ответственности перед обществом и отдельными его членами.

Очевидно, что результатом этого неверия в государство как ответственного «патера», готового прийти на помощь в трудную минуту, становится пусть медленное, преодолевающее разнообразные законодательные преграды развитие НКО, волонтерства, правозащитных и прочих организаций - всего того, что можно назвать выстраиванием коллективизма «снизу», что дает шанс эволюционным путем начать размывать ту институциональную структуру, которая представляется незыблемой в своей основе сторонникам матричных конструкций. Правда, для успешности этого процесса, в терминах Д. Норта и его коллег именуемого переходом к порядкам открытого доступа, важно не только достижение элитой пороговых условий, открывающих возможность такого перехода: не менее существенно и то, что особые пороговые условия должны быть достигнуты и обществом (подробнее см. [Плискевич 2013]). Только в таких условиях может начаться качественное давление со стороны общества на элиты (или квазиэлиты), которые в нашем случае во многом состоят из промежуточных выгодоприобретателей. В этой ситуации возможен путь к существенному перераспределению от коллективизма «сверху» к коллективизму «снизу», а значит, развитие нового качества и экономических, и политических, и социально ориентированных ассоциаций, что, собственно, и означает формирование гражданского общества. Этот тезис, кстати, вписывается в рамки теории реформ, разработанной В.М. Полтеровичем. Он подчеркивает важность сильного государства для процесса реформирования. Но сила государства выражается не в подавлении всех и вся, а в направленности на рост эффективности экономики и создание обстановки взаимного доверия и сотрудничества между государством, бизнесом и обществом. Важно, чтобы государство не боялось, а, напротив, содействовало формированию гражданского общества. Послед- 
нее рассматривается В.М. Полтеровичем как «важнейший фактор экономического развития, способствующий решению проблем координации и смягчению эффектов несостоятельности как государства, так и рынка» [Полтерович 2007, с. 427].

Таким образом, в обществах, относящихся к нуждающимся в модернизации, при создании планов их реформирования жизненно значимо противопоставление не «индивидуализма - коллективизма», а «индивидуализма - патернализма». В каждом случае и на каждом этапе развития важен поиск собственной точки наиболее продуктивного баланса между общим государственным руководством и проявлением наиболее широкой индивидуальной инициативы (разумеется, некриминального характера). Создание дополнительных легальных возможностей в тех областях, где вполне можно было бы обойтись без государственной патерналистской поддержки, сформирует шансы для сужения ее сферы и со временем соответствующих изменений в целевых ориентациях большинства индивидов. В этом процессе постепенного перекладывания решения многих актуальных для общества проблем бесспорная ответственность возлагается на властную элиту общества, призванную обеспечить и политические, и законодательные, и социально-экономические условия для постепенного сужения сферы часто принудительного коллективизма «сверху» при одновременном развитии разнообразных форм коллективизма «снизу», установления между ними гармоничного баланса. Здесь вновь стоит вспомнить теорию Норта-Уоллиса-Вайнгаста о тех пороговых условиях, только преодолев которые элита окажется способной не к конфронтации, а к сотрудничеству с гражданским обществом как выразителем коллективизма «снизу». Поиск такого баланса и составляет «особый путь» для каждой страны в самом прямом, а не идеологизированном смысле.

В то же время при разработке конкретных мер, способствующих сбалансированному функционированию государственной власти и гражданского общества, стоит помнить, что история предшествующего развития нашей страны (path dependence), причем не только ошибок, совершенных в последние десятилетия, породила целый комплекс институциональных ловушек, в которые попадают как новые реформаторы, так и контрреформаторы. Все это следует предвидеть при разработке вектора реформ, причем в условиях, осложненных тем, что в ситуации качественно новой информационной, цифровой экономики стране вновь предстоит догонять вырвавшихся вперед конкурентов, поскольку модернизация предполагает не только простое восприятие новых технологий у передовых стран, но и комплексное создание соответствующей им социокультурной среды. Для нас эта задача особенно сложна, так как Россия за свою долгую историю прошла несколько попыток модернизации мобилизационного типа. А такой тип модернизации не может быть проведен иначе, нежели на базе укрепления наличного традиционалистского социокультурного фундамента. В результате институциональная структура получает «институциональные рубцы», не известные передовым странам [Плискевич 2016].

Поэтому учет наличия таких «рубцов», а также определение путей разблокировки связанных с ними ценностей значительной части населения создает дополнительные сложности при формировании и реализации дорожной карты отечественной модернизации. Все это придает специфику российскому «особому пути» к созданию зрелого государства с порядками открытого доступа. Очевидно, что путь этот сложен, чреват новыми срывами и неизвестными ранее проблемами, но это определенно не движение в тупик. 


\section{Литература}

Ахиезер А.С. (1997) Россия: критика исторического опыта (Социокультурная динамика России). Т. І. От прошлого к будущему. Новосибирск: Сибирский хронограф.

Ахиезер А.C. (1998) Россия: критика исторического опыта (Социокультурная динамика России). Т. ІІ. Теория и методология. Словарь. Новосибирск: Сибирский хронограф.

Ахиезер А.С. (2008) Человек в поисках полноты бытия // Ахиезер А.С. Труды. Т. II. М.: Новый хронограф.

Бессонова О.Э. (2015) Рынок и раздаток в российской матрице: от конфронтации к интеграции. М.: РОССПЭН.

Бессонова О.Э. (2018) Интегрально-институциональная парадигма и российский путь: преодоление концепций «власти-собственности» и X-Y матриц // Общественные науки и современность. № 4. С. 128-143.

Бусыгина И.М., Филиппов М.Г. (2012) Политическая модернизация государства в России: необходимость, направления, издержки, риски. М.: Фонд «Либеральная миссия».

Васильев Л.С. (1994) История Востока. Т. І. Вводная часть. Сущность проблематики. М.: Высшая школа.

Грейф А. (2015) Институты и путь к современной экономике. Уроки средневековой торговли. М.: ВШЭ.

Дубин Б.В. (2018) Мифологема «особого пути» в общественном мнении современной России // Велижев М.Б., Атнашев Т.М., Зорин А.Л. (сост.) «Особый путь»: от идеологии к методу. М.: Новое литературное обозрение. С. 243-274.

Живов В.М. (2018) Особый путь и пути развития в России // Велижев М.Б., Атнашев Т.М., Зорин А.Л. (сост.) «Особый путь»: от идеологии к методу. М.: Новое литературное обозрение. С. 55-105.

Заостровцев А.П. (2017) Матрица Московии и ее реинкарнации: как реальность опровергает благие пожелания // Общественные науки и современность. № 6. С. 67-76.

Зорин А.Л. (2018) «Особый путь России» - идея трансформационного прорыва в русской культуре // Велижев М.Б., Атнашев Т.М., Зорин А.Л. (сост.) «Особый путь»: от идеологии к методу. М.: Новое литературное обозрение. С. 36-51.

Кирдина С.Г. (2014) Институциональные матрицы и развитие России: введение в Х-Ү-теорию. М., СПб.: Нестор-История.

Колганов А.И. (2017) К критике концепции «власти-собственности» // Вопросы экономики. № 7. С. 79-95.

Латов Ю.В., Нуреев Р.М. (2017) Развилки развития российской власти-собственности в «век-волкодав» 1917-2017 гг. // Заостровцев А.П. (ред.) Россия 1917-2017: Европейская модернизация или особый путь? СПб.: Леонтьевский центр. С. 28-45.

Мейер К., Хессель М., Лорш Д. (1996) Корпоративное управление. Владельцы, директора и наемные работники акционерного общества. М.: Джон Уайли энд Санз.

Норт Д., Уоллис Д., Вайнгаст Б. (2011) Насилие и социальные порядки. Концептуальные рамки для интерпретации письменной истории человечества. М.: Издательство Института Гайдара.

Нуреев Р.М., Рунов А.Б. (2002) Назад к частной собственности или вперед к частной собственности? // Общественные науки и современность. № 5. С. 5-23.

Оболонский А.В. (2016) Этика публичной сферы и реалии политической жизни. М.: Мысль.

Оболонский А.В. (2018) Химера особого пути - дорога в цивилизационный тупик // Оболонский А.В. (ред.) «Особый путь» страны. Мифы и реальность. М.: Мысль. С. 11-54.

Общественное мнение-2016. Ежегодник (2017). М.: Левада-Центр.

Пивоваров Ю.С. (2014) Русское настоящее и советское прошлое. М., СПб.: Центр гуманитарных инициатив, Университетская книга.

Плискевич H.M. (2013) Возможности трансформации в России и концепция Норта-Уоллиса- Вайнгаста. Статья 2. Пороговые условия перехода для общества // Общественные науки и современность. № 6. С. 45-60. 
Плискевич Н.M. (2016) “Path dependence” и проблемы модернизации мобилизационного типа // Мир России. Т. 25. № 2. С. 123-143.

Плискевич Н.М. (2018) Архаичный патернализм как органическая часть системы «властьсобственность» // Общественные науки и современность. № 1. С. 17-32.

Полтерович В.М. (2007) Элементы теории реформ. М.: Экономика.

Тамбовцев В.Л. (2017) Культура как основание «особого пути»: несколько критических замечаний // Заостровцев А.П. (ред.) Россия 1917- 2017: Европейская модернизация или особый путь? СПб.: Леонтьевский центр. С. 119-133.

Травин Д.Я. (2018) Почему ищут особый путь... которого нет // Оболонский А.В. (ред.) «Особый путь» страны. Мифы и реальность. М.: Мысль. С. 55-120.

Фридман М. (2006) Капитализм и свобода. М.: Новое издательство.

Хантингтон С. (2004) Политический порядок в меняющихся обществах. М.: Прогресс-Традиция.

Хедлунд С. (2015) Невидимые руки, опыт России и общественная наука. Способы объяснения системного провала. М.: ВШЭ.

Шкаратан О.И., Ястребов Г.А. (ред.) (2016) Нова ли новая Россия? М.: Университетская книга. Эйзенштадт Ш. (2010) Срывы модернизации // Неприкосновенный запас. № 6. С. 42-67.

Яковлев А.А. (2006) Агенты модернизации. М.: ВШЭ.

Eisenstadt S. (1966) Modernisation: Protest and Change, Englewood Cliffs: Prentice-Hall.

Eisenstadt S. (1973) Tradition, Change and Modernity, N.Y.: John Wiley \& Sons.

Hedlund S. (2017) The Attraction of Extraction: Fundamental Institutions of Russian Long-Term Develepment Strategy // Заостровцев А.П. (ред.) Россия 1917-2017: Европейская модернизация или особый путь? СПб.: Леонтьевский центр. С. 11-27.

Hellman J. (1998) Winners Take. All the Politics of Purtial Reform in Postcommunist Transition // World Politics, vol. 50, no 2, pp. 203-234.

\title{
Sonderweg: Myths, Reality and the Search for a Way Out
}

\author{
N. PLISKEVICH*
}

\begin{abstract}
*Nataliya Pliskevich - Senior Researcher, Institute of Economics of the Russian Academy of Sciences. Address: 32, Nakhimovskij Av., Moscow, 117218, Russian Federation. E-mail: ons@naukaran.com
\end{abstract}

Citation: Pliskevich N. (2019) Sonderweg: Myths, Reality and the Search for a Way Out. Mir Rossii, vol. 28, no 2, pp. 42-62 (in Russian). DOI: 10.17323/1811-038X-2019-28-2-42-62

\begin{abstract}
The ideas about Sonderweg in any given country (the idiosyncratic path of a country's development) typically lead to specific theoretical constructions. Such ideas usually emerge when society accumulates concern about its backwardness with respect to its neighbors, or experiences frustration after a failed attempt to modernize by borrowing institutions from more successful countries. In the latter cases, it is often ignored that
\end{abstract}


borrowed institutions evolved in donor countries as a result of a long evolutionary development constituting these countries' own Sonderweg. This article attempts three things: (1) to identify the ideologeme of Sonderweg and its role in socio-economic, political and ideological processes in Russia; (2) to highlight the features of the historical, geographical, cultural and socio-economic situation that underlie the "specifics" of Russia's development; (3) to offer insights on how to overcome path dependence and the barriers that hinder modernization.

The article shows that often it is the state that imposes the ideologeme of Sonderweg on society and uses it for its own political purposes. At the same time, it is stressed that it is difficult to build a path towards real modernization, especially in the modern information world, since this path must take into account the "institutional seam" of previous aborted attempts to modernize. In this context, the state has a prominent role to play, and it is required to take a flexible approach to solving current problems, not through overregulation of all processes, which results in a monopoly of collectivism "from above", but by encouraging the initiatives of society itself, creating independent organizations, which for many individuals turn out to be manifestations of collectivism "from below" "or, in other words, factors in the building of civil society". The harmonious relationship between the state and civil society underlies the well-being of modern developed countries.

Key words: special path, modernization, ideology, institutional structures, path dependence, institutional scars, individualism-paternalism, collectivism from above, collectivism from below

\section{References}

Akhiezer A.S. (2008) Chelovek v poiskakh polnoty bytiya [Man in Search of the Fullness of Being]. Akhiezer A.S. Trudy. T. II [Proceedings. Vol. II], Moscow: Novij khronograf.

Akhiezer A.S. (1997) Rossiya: kritika istoricheskogo opyta (Sotsiokul'turnaya dinamika Rossii). T. I. Ot proshlogo k budushchemu [Russia: A Critique of Historical Experience (Sociocultural Dynamics of Russia). Vol. I. From the Past to the Future], Novosibirsk: Sibirskij khronograf. Akhiezer A.S. (1998) Rossiya: kritika istoricheskogo opyta (Sotsiokulturnaya dinamika Rossii).T. II. Teoriya i metodologiya. Slovar'[Russia: Critique of the Historical Experience (Sociocultural Dynamics of Russia). Vol. II. Theory and Methodology. Dictionary], Novosibirsk: Sibirskij khronograf.

Bessonova O.E. (2015) Rinok i razdatok v rossijskoj matritse: ot konfrontatsii k integratsii [Market and Razdatok in the Russian Matrix: from Confrontation to Integration], Moscow: ROSSPEN.

Bessonova O.E. (2018) Integral'no-institutsional'naya paradigma i rossijskij put': preodolenie kontseptsij vlasti-sobstvennosti i X-Y-matrits [The Integral-institutional Paradigm and the Russian Path: Overcoming the Concepts of "Power-Property" and X-Y-Matrices]. Obshchestvennye nauki i sovremennost', no 4, pp. 128-143.

Busigina I.M., Filippov M.G. (2012) Politicheskaya modernizatsiya gosudarstva v Rossii: neobkhodimost', napravleniya, izderzhki, riski [Political Modernization of the State in Russia: Necessity, Directions, Costs, Risks], Moscow: Fond «Liberal'naya missiya».

Dubin B. (2018) Mifologema osobogo puti v obshchestvennom mnenii sovremennoj Rossii [The Mythologem of Sonderweg in the Public Opinion of Modern Russia]. "Osobyj put'»: ot ideologii k metodu [Sonderweg: from Ideology to Method] (eds. Velizhev M.B., Atnashev T.M., Zorin A.L.), Moscow: Novoe literaturnoe obozrenie, pp. 243-274. 
Eisenstadt S. (1966) Modernisation: Protest and Change, Englewood Cliffs: Prentice-Hall.

Eisenstadt S. (2010) Sryvy modernizatsii [Failures of Modernization]. Neprikosnovennij zapas, no 6, pp. 42-67.

Eisenstadt S. (1973) Tradition, Change and Modernity, New York: John Wiley \& Sons.

Friedman M. (2006) Kapitalizm $i$ svoboda [Capitalism and Freedom], Moscow: Novoe izdatel'stvo.

Greif A. (2015) Instituty i put'k sovremennoj ekonomike. Uroki srednevekovoj torgovli [Institutions and the Path to the Modern Economy: Lessons from Medieval Trade], Moscow: HSE.

Hedlund S. (2015) Nevidimye ruki, opyt Rossii i obshchestvennaya nauka. Sposoby ob 'yasneniya sistemnogo provala [Invisible Hands, Russian Experience and Social Science. Approaches to Understanding Systemic Failure], Moscow: HSE.

Hedlund S. (2017) The Attraction of Extraction: Fundamental Institutions of Russian Long-Term Develepment Strategy. Rossiya 1917-2017: Evropejskaya modernizatsiya ili osobyj put'? [Russia 1917-2017: European Modernization or Sonderweg?] (ed. Zaostrovtsev A.P.), Saint Petersburg: Leontevskij tsentr, pp. 11-27.

Hellman J. (1998) Winners Take. All the Politics of Purtial Reform in Postcommunist Transition. World Politics, vol. 50, no 2, pp. 203-234.

Huntington S.P. (2004) Politicheskij poryadok v menyayushchikhsya obshchestvakh [Political Order in Changing Societies], Moscow: Progress-Traditsiya.

Kirdina S.G. (2014) Institutsional'nye matritsy $i$ razvitie Rossii. Vvedenie $v$ X-Y-teoriyu. [Institutional Matrices and Development in Russia: An Introduction to X and Y Theory]. $3^{\text {rd }}$ edition, Moscow, Saint Petersburg: Nestor Istoriya.

Kolganov A.I. (2017) K kritike kontseptsii vlasti-sobstvennosti [On the Criticism of the Concept of "Power-Property"]. Voprosi ekonomiki, no 7, pp. 79-95.

Latov Yu.V., Nureev R.M. (2017) Razvilki razvitiya rossijskoj vlasti-sobstvennosti v vekvolkodav 1917-2017 gg. [The Fork of Russia's Power-Property Development in 1917-2017]. Rossiya 1917-2017: Evropejskaya modernizatsiya ili osobyj put'? [Russia 1917-2017: European Modernization or Sonderweg?] (ed. Zaostrovtsev A.P.), Saint Petersburg: Leontevskij tsentr, pp. 28-45.

Mayer K., Hessel M., Lorsh D. (1995) Korporativnoe upravlenie. Vladeltsy, direktora i naemnye rabotniki aktsionernogo obshchestva [Corporate Governance. Owners, Directors and Employees of a Joint Stock Company], Moscow: John Wayli and Sanz.

North D., Wallis J., Weingast B. (2011) Nasilie i sotsial'nye poryadki. Kontseptual'nye ramki dlya interpretatsii pis'mennoj istorii chelovechestva [Violence and Social Order: A Conceptual Framework for Interpreting Recorded Human History], Moscow: Institut Gajdara.

Nureev R.M., Runov A.B. (2002) Nazad k chastnoj sobstvennosti ili vpered k chastnoj sobstvennosti? [Back to Private Property or Forward to Private Property?]. Obshchestvennye nauki i sovremennost', no 5, pp. 5-23.

Obolonskij A.V. (2016) Etika publichnoj sfery i realii politicheskoj zhizni [Ethics of the Public Sphere and the Realities of Political Life], Moscow: Misl'.

Obolonskij A.V. (2018) Khimera osobogo puti - doroga v tsivilizatsionnij tupik [The Chimera of Sonderweg - a Road to a Civilizational Deadlock]. Osobyj put'strany. Mify $i$ realnost' [Sonderweg. Myths and Reality] (ed. Obolonskij A.V.), Moscow: Misl', pp. 11-54.

Obshchestvennoe mnenie-2016. Ezhegodnik [Public Opinion-2016. Yearbook] (2017), Moscow: Levada-Centre.

Pivovarov Yu.S. (2014) Russkoe nastoyaschee i sovetskoe proshloe [Russian Present and Soviet Past], Moscow, Saint-Petersburg: Tsentr gumanitarnikh initsiativ, Universitetskaya kniga.

Pliskevich N.M. (2013) Vozmozhnosti transformatsii v Rossii i kontseptsiya Norta-Uollisa-Vayngasta. Stat'ya 2. Porogovye usloviya perekhoda dlya obshchestva [Transformation Opportunities in Russia and the Concept of North-Wallis-Waingast. Article 2. The Threshold Conditions for the Transition to Society]. Obshchestvennye nauki i sovremennost', no 6, pp. 45-60.

Pliskevich N.M. (2016) "Path dependence" i problemi modernizatsii mobilizatsionnogo tipa ["Path Dependence" and the Problems of Mobilizing Modernization]. Mir Rossii, no 2, pp. 123-143.

Pliskevich N.M. (2018) Arkhaichnij paternalizm kak organicheskaya chast' sistemy vlastsobstvennost' [Archaic Paternalism as an Organic Part of the "Power-Property" System]. Obshchestvennye nauki i sovremennost', no 1, pp. 17-32. 
Polterovich V.M. (2007) Elementy teorii reform [Elements of the Reform Theory], Moscow: Ekonomika.

Shkaratan O.I., Yastrebov G.A. (eds.) (2016) Nova li novaya Rossiya? [Is New Russia New?], Moscow: Universitetskaya kniga.

Tambovtsev V.L. (2017) Kultura kak osnovanie osobogo puti: neskol'ko kriticheskikh zamechanij [Culture as a Basis of Sonderweg: a Few Critical Remarks]. Rossiya 1917-2017: Evropejskaya modernizatsiya ili osobyj put'? [Russia 1917-2017: European Modernization or Sonderweg?] (ed. Zaostrovtsev A.P.), Saint Petersburg: Leontevskij tsentr, pp. 119-133.

Travin D.Ya. (2018) Pochemu ishchut osobyj put'... kotorogo net [Why Are They Searching for a Sonderweg... Which Does not Exist]. Osobyj put' strany. Mify i realnost' [Sonderweg. Myths and Reality] (ed. Obolonskij A.V.), Moscow: Misl', pp. 55-120.

Vasilev L.S. (1994) Istoriya Vostoka. T. I. Vvodnaya chast'. Sushchnost' problematiki [History of the East. Vol. I. Introduction. The Essence of the Problem], Moscow: Visshaya shkola.

Zaostrovtsev A.P. (2017) Matritsa Moskovii i ee reinkarnatsii: kak realnost' oprovergaet blagie pozhelaniya [The Muscovy Matrix and Its Reincarnation: How Reality Refutes Good Wishes]. Obshchestvennye nauki i sovremennost', no 6, pp. 67-76.

Zhivov V.M. (2018) Osobyj put' i puti razvitiya v Rossii [Sonderweg and Russia's Paths of Development]. «Osobyj put'»: ot ideologii k metodu [Sonderweg: from Ideology to Method] (eds. Velizhev M.B., Atnashev T.M., Zorin A.L.), Moscow: Novoe literaturnoe obozrenie, pp. 55-105.

Zorin A.L. (2018) "Osobyj put' Rossii” ideya transformatsionnogo proryva v russkoj kult'ure [Russia's Sonderweg - the Idea of a Transformational Breakthrough in Russian Culture]. "Osobyj put'": ot ideologii k metodu ["Sonderweg: from Ideology to Method] (eds. Velizhev M.B., Atnashev T.M., Zorin A.L.), Moscow: Novoe literaturnoe obozrenie, pp. 36-51.

Yakovlev A.A. (2006) Agenty modernizatsii [Modernization Agents], Moscow: HSE. 